\title{
ROLA DYNAMICZNYCH WSKAŹNIKÓW PŁYNNOŚCI FINANSOWEJ W ZARZĄDZANIU PRZEDSIĘBIORSTWEM
}

\author{
Katarzyna Białas \\ Wydział Ekonomiczno-Socjologiczny \\ Uniwersytet Łódzki
}

\section{Streszczenie:}

Cel - Celem artykułu jest wskazanie roli i znaczenia danych dotyczących płynności finansowej uzyskanych za poprzez statyczne wskaźniki płynności a alternatywne, dynamiczne wskaźniki płynności finansowej, z punktu widzenia kadry zarządzającej przedsiębiorstwem.

Metodologia badań - $\mathrm{W}$ artykule dokonana została analiza danych finansowych spółki $\mathrm{X}$ notowanej na GPW w Warszawie, z punktu widzenia zarządzania posiadaną płynnością finansową. Analiza ta została przeprowadzona w dwóch podejściach: statycznym i dynamicznym.

Wynik - Badanie pozwoliło ocenić przydatność informacyjną danych wskaźników, z punktu widzenia kadry zarządzającej oraz strategicznego zarządzania środkami pieniężnymi w kontekście maksymalizacji zysku dla właścicieli.

Oryginalność/wartość - Przedstawione badanie pozwoliło ocenić, czy wartości wskaźnikowe w adekwatny sposób odzwierciedlają sytuację bieżącą przedsiębiorstwa. Informacje te pozwalają kadrze zarządzającej na racjonalne zarządzania finansami, które umożliwia terminową spłatę zobowiązań, finansowanie inwestycji i długoterminowego rozwoju na rynku.

Słowa kluczowe: płynność finansowa, zarządzanie przedsiębiorstwem, wskaźniki dynamiczne.

JEL Class: G17. 


\section{WPROWADZENIE}

W obecnej, niezwykle szybko rozwijającej się, konkurencyjnej gospodarce, zachowanie płynności finansowej jest kluczowym wyznacznikiem wypłacalności, rozwoju i kontynuacji działalności przedsiębiorstw. Stąd wzrost znaczenia analizy przepływów pieniężnych w efektywnym, strategicznym zarządzaniu przedsiębiorstwem. Odpowiednio dobrane wskaźniki umożliwiają wskazanie i obiektywną ocenę rzeczywistego stanu przedsiębiorstwa. Analiza ta dotyczy głównie zaakcentowania jego mocnych stron oraz działalności, która w największym stopniu wpływa na spadek jego rentowość, a zatem obniża zyski dla właścicieli.

Można zatem sformułować tezę, iż dynamiczne wskaźniki płynności finansowej uwzgledniające rzeczywiste przepływy pieniężne generowane w trakcie działalności przedsiębiorstwa, w znacznym stopniu rzetelniej odzwierciedlają sytuacje finansową jednostki niż klasyczne wskaźniki płynności, odnoszące się do konkretnego momentu, bazując na statycznych sprawozdaniach finansowych.

Ocena płynności finansowej jest najczęściej oceniana jedynie przez pryzmat całościowej oceny rachunku przepływów pieniężnych. Analiza ta bazuje na klasycznych wskaźnikach statycznych, które obrazują poziom zdolności obsługi zobowiązań, wyłącznie w momencie sporządzenie sprawozdania. Jednak z punktu zarządzania przedsiębiorstwem, więcej informacji niosą wskaźniki oparte na przyszłych strumieniach pieniężnych generowanych $\mathrm{z}$ posiadanych aktywów, tj. dynamiczne wskaźniki płynności finansowej.

Celem artykułu jest ukazanie możliwości informacyjnych jakie niesie zastosowanie w analizie finansowej dynamicznych wskaźników płynności. Kluczowe jest również porównanie płynności finansowej ocenianej z punktu standardowych, statycznych wskaźników płynności a wskaźników dynamicznych, które skupione są na bardziej szczegółowych aspektach działalności finansowej przedsiębiorstw. Ocena sytuacji finansowej spółek poprzez dwie grupy wskaźników pozwala na szerszą analizę sytuacji wewnętrznej podmiotów oraz wcześniejsze zasygnalizowanie nieprawidłowości w polityce pieniężnej firm.

\section{ZASTOSOWANIE WSKAŹNIKÓW STATYCZNYCH I DYNAMICZNYCH PŁYNNOŚCI FINANSOWEJ}

Efektywna ocena sytuacji finansowej przedsiębiorstwa umożliwia zastosowanie odpowiedniej strategii zarządzania środkami finansowymi. Przekłada się to na efektywniejszą politykę finansową, która przekłada się bezpośrednio na maksymalizację zysku właścicieli, co jest głównym celem działalności przedsiębiorstwa. Jest to możliwe dzięki szczegółowej analizie finansowej realizowanej działalności. W celu optymalnego zarządzania przedsiębiorstwem niezbędne jest 
zatem sporządzanie rachunku przepływów pieniężnych, który dostarcza istotnych informacji o źródłach posiadanych środków pieniężnych w poszczególnych okresach oraz o kierunkach ich wydatkowania. Umożliwia ocenę gromadzenia, jak i wydatkowania środków pieniężnych, a także dostosowywanie swojej polityki pieniężnej do założeń prowadzonej długookresowej strategii rozwojowej [Kowalska 2013: 223-224]. Działania dążące do utrzymania odpowiedniego poziomu płynności przedsiębiorstwa warunkują normalne funkcjonowanie firmy, determinują realizacje jego zadań, jak również pozycje na rynku. Niedobory w zakresie płynności skutkują usztywnieniem zakresu działań podejmowanych przez przedsiębiorstwo. Utrata elastyczności działania, w aktualnie niezwykle zmiennych warunkach gospodarczych, może spowodować konieczność wprowadzenia procesu restrukturyzacji. W ostateczności może nawet doprowadzić do upadłości podmiotu. Kluczową kwestią jest zatem bieżący monitoring poziomu utrzymywanej płynności finansowej [Śnieżek i Wiatr 2015: 774-781].

Powszechnie stosowane wskaźniki statyczne, oparte na pozycjach bilansowych, badają jedynie płynność krótkoterminową. Nie uwzględniają natomiast problemu niepokrywania się terminów płatności należności i zobowiązań, a zatem także wielkości generowanego zapotrzebowania na środki obrotowe. Ocena powyższych miar płynności stanowi trudność, ze względu na ogólnie przyjęte wielkości graniczne określone przez literaturę. W przypadku szybko rozwijającej się gospodarki, ich ocena staje się mało miarodajna. Nie uwzględniają one takich czynników, jak średnie wartości sektorowe, specyfika branży bądź działalności oraz dostępu do kapitału. Są one także narażone na większe manipulacje ze strony kard zarządzających, w celu poprawy obrazu przedsiębiorstwa dla kontrahentów i potencjalnych inwestorów [Gołębiowski i in. 2014: 166-173].

Wskaźniki klasyczne nie uwzględniają problemu niepokrywania się terminów płatności należności i zobowiązań, a zatem także wielkości generowanego zapotrzebowania na środki obrotowe. Dlatego też, z punktu zarządzania przedsiębiorstwem, więcej informacji niosą wskaźniki oparte na przyszłych strumieniach pieniężnych generowanych $\mathrm{z}$ posiadanych aktywów, tj. dynamiczne wskaźniki płynności finansowej [Niemiec 2014: 57-59].

Dynamiczne wskaźniki płynności są stosunkowo niedocenianą grupą wskaźników finansowych. Bazując na przepływach pieniężnych, wykazanych w sprawozdaniu z przepływów pieniężnych, pozwalają zbadać mechanizmy wywołujące zmiany posiadanych wielkości zasobów pieniężnych. Uzyskane informacje są wykorzystywane m.in. do:

- analizy i planowania finansowego, głównie z punktu strategii wzrostu wartości dla akcjonariuszy,

- oceny efektywności realizowanych projektów inwestycyjnych,

- wyceny przedsiębiorstwa,

- prognozowania upadłości. 
Wskaźniki te identyfikują najważniejsze segmenty działalności generujące wpływy i wydatki środków pieniężnych oraz ich relacji i wpływu na osiągany zysk [Wajszczuk 2013: 114-115].

Kwestia płynności finansowej często bywa niedoceniana. Jednak z punktu kontroli finansowych symptomów ostrzegawczych, jest źródłem cennych informacji $\mathrm{w}$ zakresie sterowania generowanymi przepływami pieniężnymi. Brak odpowiedniej wiedzy, zarówno teoretycznej, jak i praktycznej, powoduje trudności w rozpatrywaniu głównych przyczyn pogorszenia sytuacji finansowej przedsiębiorstwa [Nesterak 2014: 48-53].

Pomiar płynności w dynamicznym ujęciu, dotyczy zarówno okresów historycznych, jak i przyszłych. Ujęcie ex post analizuje przepływy z poszczególnych sfer działalności w oparciu o dane generowane przez rachunek cash flow. Natomiast ujęcie ex ante wykorzystywane jest przy bieżącym zarządzaniu płynnością i jest bazą do prognoz przepływów pieniężnych na przyszłe okresy. Sygnalizuje również trudności $\mathrm{w}$ utrzymaniu wymaganej płynności $\mathrm{w}$ dalszym toku prowadzenia działalności. Tym samym umożliwia wczesne podjęcie działań w celu zachowania zdolności do terminowego regulowania zobowiązań i zakładanych inwestycji [Kreczmańska-Gigol 2015: 248-252].

Podział powszechnie stosowanych wskaźników płynności został zaprezentowany w tab. 1.

Wskaźniki wydajności i wystarczalności gotówkowej, dają bardziej rzetelne informacje od powszechnie używanych, ogólnych wskaźników statycznych. $\mathrm{Z}$ tego względu powinny być wykorzystywane jako alternatywne źródło informacji w obszarze zarządzania płynnością, rentownością czy poziomem zadłużenia. Trudnością jest z pewnością brak określonych ram dla tych wskaźników. Jednak ocena płynności finansowej powinna być indywidualnie dopasowana do rodzaju prowadzonej działalności danego podmiotu gospodarczego, uwzględniając rynek, branżę oraz prowadzoną politykę zarządzania kapitałem obrotowym przy danej strukturze finansowania [Tokarski i in. 2014: 58-63].

Wciąż, najczęściej analizowanymi wskaźnikami płynności są wskaźniki statyczne. Mierniki te charakteryzują się konstrukcją, która umożliwia ocenę przedsiębiorstwa niezależnie od jego rozmiarów. Pozwala to na porównywanie zróżnicowanych przedsiębiorstw między sobą. Umożliwia monitoring zmiany poziomu płynności w czasie, pomimo nawet znacznych zmian jego wielkości. Powyższe podejście dominuje, pomimo faktu, iż istotą płynności jest synchronizacja generowanych wpływów i wydatków środków pieniężnych [Kusak 2004: 10]. Często błędnie pomijany jest fakt, iż stany bilansowe kształtowane są pod wpływem dynamiki strumieni pieniężnych. Jednak w ciągu ostatnich lat poglądy dotyczące praktyk gospodarczych uległy zmianie. 
Tabela 1. Podział wskaźników płynności finansowej

\begin{tabular}{|c|c|c|}
\hline \multicolumn{3}{|c|}{ Wskaźniki płynności finansowej } \\
\hline $\begin{array}{l}\text { Statyczne wskaźniki } \\
\text { płynności }\end{array}$ & \multicolumn{2}{|r|}{ Dynamiczne wskaźniki płynności } \\
\hline \multirow{27}{*}{$\begin{array}{l}\text { Wskaźnik płynności } \\
\text { bieżącej (CR - current } \\
\text { ratio) - III stopień } \\
\text { płynności }\end{array}$} & \multirow{7}{*}{$\begin{array}{l}\text { Wskaźniki } \\
\text { wydajności } \\
\text { pieniężnej: }\end{array}$} & - Wskaźnik wydajności gotówkowej sprzedaży \\
\hline & & - Wskaźnik wydajności gotówkowej zysku \\
\hline & & - Wskaźnik gotówkowej wydajności majątku \\
\hline & & - Wskaźnik gotówkowej wydajności majątku trwałego \\
\hline & & - Wskaźnik wydajności gotówkowej majątku obrotowego \\
\hline & & - Wskaźnik pieniężnej wydajności kapitału własnego \\
\hline & & - Wskaźnik. pieniężnej nadwyżki operacyjnej na 1 akcję \\
\hline & \multirow{7}{*}{$\begin{array}{c}\text { Wskaźniki } \\
\text { wystarczalno- } \\
\text { ści pieniężnej: }\end{array}$} & - Wskaźnik ogólnej wystarczalności pieniężnej \\
\hline & & $\begin{array}{l}\text { - Wskaźnik wystarczalności pieniężnej na zakup śr. } \\
\text { trwałych }\end{array}$ \\
\hline & & - Wskaźnik spłacalności ogółu zadłużenia \\
\hline & & - Pieniężny wskaźnik pokrycia zob. odsetkowych \\
\hline & & $\begin{array}{l}\text { - Wskaźnik udziału amortyzacji w przyroście śr. pie- } \\
\text { niężnych }\end{array}$ \\
\hline & & - Wskaźnik wypłaty dywidend \\
\hline & & - Pieniężny wskaźnik pokrycia dywidend \\
\hline & \multirow{6}{*}{$\begin{array}{l}\text { Wskaźniki } \\
\text { działalności } \\
\text { operacyjnej: }\end{array}$} & - Wskaźnik ogólnej wystarczalności gotówki operacyjnej \\
\hline & & $\begin{array}{l}\text { - Wskaźnik wystarczalności gotówki operacyjnej na } \\
\text { spłatę zobowiązań ogółem }\end{array}$ \\
\hline & & $\begin{array}{l}\text { - Wskaźnik wystarczalności gotówki operacyjnej na } \\
\text { spłatę zobowiązań długoterminowych }\end{array}$ \\
\hline & & $\begin{array}{l}\text { - Wskaźnik wystarczalności gotówki operacyjnej na } \\
\text { spłatę zobowiązań bieżących }\end{array}$ \\
\hline & & $\begin{array}{l}\text { - Wskaźnik udziału zysku netto w operacyjnych prze- } \\
\text { pływach pieniężnych netto }\end{array}$ \\
\hline & & $\begin{array}{l}\text { - Wskaźnik zdolności do generowania środków pienięż- } \\
\text { nych z dział. operacyjnej }\end{array}$ \\
\hline & \multirow{4}{*}{$\begin{array}{c}\text { Wskaźniki } \\
\text { działalności } \\
\text { inwestycyjnej: }\end{array}$} & - Pieniężny wskaźnik finansowania dział. inwestycyjnej \\
\hline & & $\begin{array}{l}\text { - Wskaźnik udziału wydatków inwestycyjnych } \\
\text { w wydatkach ogółem }\end{array}$ \\
\hline & & - Pieniężny wskaźnik pokrycia wydatków kapitałowych \\
\hline & & $\begin{array}{l}\text { - Wskaźnik zdolności pokrycia wydatków dział. inwe- } \\
\text { stycyjnej i finansowej }\end{array}$ \\
\hline & \multirow{3}{*}{$\begin{array}{l}\text { Wskaźniki } \\
\text { działalności } \\
\text { finansowej: }\end{array}$} & $\begin{array}{l}\text { - Wskaźnik zależności od zewnętrznych źródeł finan- } \\
\text { sowania }\end{array}$ \\
\hline & & $\begin{array}{l}\text { - Wskaźnik pieniężnej samowystarczalności dział. } \\
\text { finansowej }\end{array}$ \\
\hline & & - Pieniężny wskaźnik obsługi długu \\
\hline
\end{tabular}

Źródło: opracowanie własne na podstawie: Śnieżek i Wiatr [2015: 642-658]. 
Coraz częściej akcentowany jest fakt, iż wzrost poziomu przychodów ze sprzedaży, bądź wartość zysku netto wypracowanego przez przedsiębiorstwo, nie są najlepszymi miernikami jej sytuacji finansowej. Jako że są to kategorie księgowe, o memoriałowym charakterze, istnieje możliwość usankcjonowanego manipulowania ich wartościami, przez co analizy na nich bazujące mają sztuczny charakter. Prowadzi to do większej świadomości dotyczącej zalet korzystania ze wskaźników bazujących na rachunku przepływów pieniężnych, które dają nowe spojrzenie na sytuację finansową podmiotu. Niezależność tego podejścia od konwencji księgowych daje wyczerpującą ocenę działalności finansowej przedsiębiorstwa [Janik i Paździor 2011: 172-177].

Dla kadry zarządzającej przedsiębiorstwem kluczowe są środki pieniężne, natomiast wypracowany zysk ma rolę drugoplanową, ponieważ to one są gwarantem wypłacalności i płynności jednostki. Analiza wskaźnikowa oparta na pozycjach rachunku przepływów pieniężnych umożliwia ocenę wielkości i terminowości ruchów przepływów gotówkowych. W dłuższym okresie stanowi ona podstawę kontroli terminowości regulowania zobowiązań. Pozwala też określić obszary, które generują, jak i pochłaniają środki finansowe, obszary powodujące potencjalne zagrożenie $\mathrm{z}$ punktu widzenia terminowości regulacji zobowiązań oraz umożliwiają porównanie $\mathrm{z}$ innymi przedsiębiorstwami, również $\mathrm{w}$ czasie. Wskaźniki dynamiczne pozwalają w pełni zidentyfikować mocne oraz słabe strony w funkcjonowaniu przedsiębiorstwa, a także określić szanse bądź zagrożenia w poszczególnych obszarach działalności [Grabowska 2012: 13-15].

\section{ANALIZA PŁYNNOŚCI FINANSOWEJ SPÓŁKI X W UJĘCIU STATYCZNYM}

Analiza płynności finansowej poprzez wskaźniki statyczne służy do bieżącej oceny zdolności do obsługi zadłużenia. Krótkoterminowa ocena jest oceniana pod kątem relacji między aktywami obrotowymi a posiadanymi zobowiązaniami krótkoterminowymi. Tabela 2 przedstawia zestawienie statycznych wskaźników płynności dla spółki X.

Wskaźniki płynności bieżącej w latach 2013-2015 ulegały znaczącym wahaniom. Tylko w 2014 r. spółka osiągnęła wartość wskaźnika na poziomie 1,33, oznaczającą bezpieczeństwo pokrycia zobowiązań bieżących przez majątek obrotowy. Natomiast w roku 2015 wskaźnik uległ znacznemu pogorszeniu (wartość 0,53 ), co jest spowodowane spadkiem aktywów obrotowych, przy równoczesnym zwiększeniu finansowania krótkoterminowego.

Wskaźniki płynności szybkiej, eliminując majątek o niskim stopniu zbywalności, bardziej realnie przedstawiają sytuację spółki. Po znacznym wzroście wskaźnika w 2014 r., spowodowanego dobrą sytuacją finansową podmiotu, 
w 2015 r. znacznie spadł on do poziomu 0,47 (spadek o ok. 250\%). Wynik ten świadczy o niskim poziomie zabezpieczenia spłaty zobowiązań bieżących. Przedkłada się to na fakt, iż w 2015 r. majątek obrotowy jest w stanie pokryć jedynie tylko 47\% zadłużenia, a to stwarza ryzyko utraty płynności przy utrzymaniu się takiej tendencji w kolejnych latach.

Tabela 2. Statyczne wskaźniki płynności finansowej spółki X w latach 2013-2015

\begin{tabular}{|l|c|c|c|}
\hline Wskaźniki & 2013 & 2014 & 2015 \\
\hline Wskaźnik płynności bieżącej & 0,91 & 1,33 & 0,53 \\
\hline Wskaźnik płynności szybkiej & 0,81 & 1,22 & 0,47 \\
\hline Wskaźnik płynności gotówkowej & 0,12 & 0,29 & 0,05 \\
\hline Wskaźnik inwestycje krótkoterminowe/zob. bieżące & 0,01 & 0,28 & 0,002 \\
\hline
\end{tabular}

Źródło: opracowanie własne na podstawie sprawozdań finansowych spółki X za lata 2013-2015.

Wskaźniki płynności gotówkowej w latach 2013-2015 znajdują się na optymalnej wartości. Znaczny spadek wskaźnika w 2015 r. spowodowany był stratą na działalności, przy jednoczesnym zwiększeniu zobowiązań bieżących. Powoduje to ryzyko wystąpienia trudności w natychmiastowej spłacie bieżących zobowiązań za pomocą środków pieniężnych.

Ostatni wskaźnik wskazuje, że spółka nie zabezpiecza płynności w znaczącej wartości poprzez inwestycje krótkoterminowe - główne zabezpieczenie stanowi majątek obrotowy. Przy zwiększonych możliwościach płatniczych w 2014 r., firma zainwestowała środków w inwestycje krótkoterminowe, stąd wysoki wskaźnik w tym roku.

Wskaźniki te, z powodu niedużej wartości informacyjnej, są najczęściej uzupełniane o analizę wskaźników rotacji majątku. Pozwala to na uzyskanie bardziej szczegółowych danych odnośnie zmian w poszczególnych segmentach majątku obrotowego, który przekłada się na uzyskanie płynności bieżącej. Znacząca jest tutaj realizowana polityka zarządzania kapitałem pracującym, który bezpośrednio wpływa na poziom bezpieczeństwa finansowego.

\section{ANALIZA PŁYNNOŚCI FINANSOWEJ SPÓŁKI X W UJĘCIU DYNAMICZNYM}

W celu dogłębnej analizy płynności, uwzględniającej czas niezbędny do zamiany aktywów bieżących na środki pieniężne, jak też czasu niezbędnego do spłaty zobowiązań, należy zastosować dynamiczne wskaźniki płynności finansowej. Wskaźniki te, obliczone dla spółki X, zostały zaprezentowane w poniższych tab. 3-7. 
Tabela 3. Wskaźniki wydajności gotówkowej spółki X w latach 2013-2015

\begin{tabular}{|l|c|c|c|}
\hline Wskaźniki wydajności gotówkowej & 2013 & 2014 & 2015 \\
\hline Wsk. wydajności gotówkowej sprzedaży & 0,21 & 0,14 & 0,18 \\
\hline Wsk. wydajności gotówkowej zysku & 2,11 & 1,43 & $-1,78$ \\
\hline Wsk. gotówkowej wydajności majątku & 0,13 & 0,08 & 0,11 \\
\hline Wsk. gotówkowej wydajności majątku trwałego & 0,15 & 0,09 & 0,12 \\
\hline Wsk. wydajności gotówkowej majątku obrotowego & 0,85 & 0,41 & 0,86 \\
\hline Wsk. pieniężnej wydajności kapitału własnego & 0,027 & 0,031 & 0,034 \\
\hline Wsk. pieniężnej nadwyżki operacyjnej na 1 akcję & 2,13 & 1,3 & 1,78 \\
\hline
\end{tabular}

Źródło: opracowanie własne na podstawie sprawozdań finansowych spółki X za lata 2013-2015.

Wydajność gotówkowa sprzedaży zmniejszyła się w badanym okresie. W 2013 r. z każdej złotówki przychodów ze sprzedaży spółka uzyskiwała $0,21 \mathrm{zł}$, natomiast w kolejnych latach było to odpowiednio 0,14 i 0,18 zł. Oznacza to pogorszenie sytuacji dla podmiotu.

W 2013 r. na złotówkę zysku działalności gospodarczej przypadało około 2,11 zł gotówki operacyjnej, w kolejnym roku było to tylko $1,43 \mathrm{zł}$, natomiast w 2015 r. była to strata wielkości -1,78 zł na działalności gospodarczej. Oznacza to niekorzystną sytuację dla spółki.

Z każdej złotówki zainwestowanej w majątek, spółka osiągnęła w 2013 r. niespełna 0,13 zł gotówki z działalności operacyjnej, w kolejnym roku była to kwota 0,08 zł, a w ostatnim już 0,11 zł. Jest to efekt wzrostu wartości majątku, przy jednoczesnym spadku przepływów z działalności operacyjnej. Największą wydajnością cechuje się majątek obrotowy, który w roku 2013 i 2015 generował około 0,85 zł gotówki operacyjnej.

W analizowanym okresie wydajność kapitału własnego ulega poprawie. Rośnie z poziomu 0,027 do 0,034 w 2015 r. (wzrost o 25\%). Dlatego już w 2015 r. na jednostkę kapitału własnego przypada 0,034 zł dodatniej pieniężnej nadwyżki operacyjnej.

Na 1 akcję zwykłą przypada w 2013 r. 2,13 zł operacyjnych przepływów pieniężnych netto, po uregulowaniu dywidend od akcji uprzywilejowanych. W kolejnym roku wartość ta spada do 1,30 zł, a w 2015 r. następuje poprawa i wzrost wskaźnika do poziomu 1,78 zł, co należy ocenić jako poprawę płynności i zwiększenie pieniężnej nadwyżki operacyjnej.

Wartości ogólnej wystarczalności gotówki operacyjnej wyższe od 1 oznaczają, że działalność operacyjna generuje wystarczającą ilość gotówki do pokrycia wydatków z tytułu: spłaty zobowiązań kredytowych, wypłaty dywidend czy też zakupu majątku trwałego. 
Tabela 4. Wskaźniki działalności operacyjnej spółki X w latach 2013-2015

\begin{tabular}{|l|c|c|c|}
\hline Wskaźniki działalności operacyjnej & 2013 & 2014 & 2015 \\
\hline Wsk. ogólnej wystarczalności gotówki operacyjnej & 1,19 & 2,13 & 1,54 \\
\hline $\begin{array}{l}\text { Wsk. wystarczalności gotówki operacyjnej na spłatę zob. } \\
\text { ogółem }\end{array}$ & 0,28 & 0,16 & 0,21 \\
\hline $\begin{array}{l}\text { Wsk. udziału zysku netto w operacyjnych przepływów } \\
\text { pieniężnych netto }\end{array}$ & 0,33 & 0,45 & $-0,53$ \\
\hline $\begin{array}{l}\text { Wsk. zdolności do generowania środków pieniężnych } \\
\text { z dział. operacyjnej }\end{array}$ & $-11,65$ & 3,02 & $-3,14$ \\
\hline
\end{tabular}

Źródło: opracowanie własne na podstawie sprawozdań finansowych spółki X za lata 2013-2015.

Gotówka operacyjna w stosunku do ogółu zobowiązań jest na niskim poziomie, osiągając wartość $0,28 \% \mathrm{w}$ roku 2013, przez $0,16 \% \mathrm{w}$ roku następnym, aż do niewielkiego wzrostu w 2015 r. do wartości $0,21 \%$, co świadczy o utrzymywaniu niskiego poziomu gotówki w stosunku do wielkości posiadanych zobowiązań.

Udział zysku netto $\mathrm{w}$ przepływach pieniężnych netto $\mathrm{z}$ działalności operacyjnej w latach 2013-2014 wzrósł z poziomu 33\% do 45\%. Natomiast w 2015 r. wartość $-53 \%$ była spowodowana stratą na działalności spółki.

Wskaźnik generowania środków pieniężnych z działalności operacyjnej ulegał znacznym wahaniom. Świadczy to o znacznych wydatkach z pozostałych działalności przedsiębiorstwa, które przewyższają wpływy z podstawowej działalności spółki, i zmniejszają wartość generowanej nadwyżki finansowej.

Tabela 5. Wskaźniki działalności inwestycyjnej spółki X w latach 2013-2015

\begin{tabular}{|l|c|c|c|}
\hline Wskaźniki działalności inwestycyjnej & 2013 & 2014 & 2015 \\
\hline Wsk. finansowania działalności inwestycyjnej & $-1,09$ & $-0,8$ & $-1,38$ \\
\hline $\begin{array}{l}\text { Wsk. udziału wydatków inwestycyjnych w wydatkach } \\
\text { ogółem }\end{array}$ & 0,52 & 0,51 & 0,38 \\
\hline $\begin{array}{l}\text { Wsk. zdolności pokrycia wydatków dział. inwestycyjnej } \\
\text { i finansowej }\end{array}$ & 0,84 & 0,47 & 0,65 \\
\hline
\end{tabular}

Źródło: opracowanie własne na podstawie sprawozdań finansowych spółki X za lata 2013-2015.

Wartość wskaźników w 2013 i 2015 r. pokazuje, iż wydatki inwestycyjne przekraczają wpływy z działalności, co przy utrzymaniu takiej tendencji w długim okresie zwiększa ryzyko finansowe działalności podmiotu. Tylko w $2014 \mathrm{r}$. bieżąca działalność inwestycyjna była pokrywana ze zgromadzonych środków. 
Wydatki inwestycyjne w latach 2013-2014 stanowiły około 51-52\% ogółu wydatków spółki, natomiast w 2015 roku wartość ta spadła do 38\%.

Zdolność spółki do pokrycia wydatków pozaoperacyjnych w 2013 r. wynosiła 84\%. Po pogorszeniu w 2014 r. (poziom 47\%), w 2015 r., dzięki wysokiej nadwyżce operacyjnej z poprzedniego okresu, nastąpił wzrost wskaźnika do poziomu $65 \%$.

Tabela 6. Wskaźniki działalności finansowej spółki X w latach 2013-2015

\begin{tabular}{|l|r|r|r|}
\hline Wskaźniki działalności finansowej & 2013 & 2014 & 2015 \\
\hline Wsk. zależności od zewnętrznych źródeł finansowania & $-0,06$ & 0,62 & $-0,16$ \\
\hline Wsk. pieniężnej samowystarczalności dział. finansowej & 0,69 & 1,79 & 0,55 \\
\hline Pieniężny wskaźnik obsługi długu & 0,18 & 0,73 & 0,33 \\
\hline
\end{tabular}

Źródło: opracowanie własne na podstawie sprawozdań finansowych spółki X za lata 2013-2015.

Wskaźnik zależności od zewnętrznych źródeł finansowania w 2013 i 2015 r. przestawia niskie przepływy finansowe, świadczące o małym zapotrzebowaniu na finansowanie zewnętrze w tym okresie. W roku 2014 wartość znacznie wzrosła do 0,62 , co świadczy o znacznym wzroście zapotrzebowania na nakłady inwestycyjne.

Niskie wskaźniki samowystarczalności działalności finansowej świadczą o przewadze wydatków nad wpływami generowanymi z tej działalności. Jedynie w 2014 r. została wygenerowana dodatnia nadwyżka z działalności finansowej w spółce.

Generowana przez spółkę nadwyżka operacyjna netto jest w stanie pokryć dług finansowy w kolejnych latach na poziomie odpowiednio: $82 \%$, 27\% i 67\%.

Tabela 7. Wskaźniki wystarczalności pieniężnej spółki X w latach 2013-2015

\begin{tabular}{|l|c|c|c|}
\hline Wskaźniki wystarczalności pieniężnej & 2013 & 2014 & 2015 \\
\hline Wsk. ogólnej wystarczalności pieniężnej & 0,88 & 0,49 & 0,41 \\
\hline Wsk. spłacalności ogółu zadłużenia & 3,57 & 6,33 & 4,73 \\
\hline Pieniężny wskaźnik pokrycia zob. odsetkowych & 10,84 & 6,24 & 7,87 \\
\hline Wsk. udziału amortyzacji w przyroście środków pieniężnych & 0,42 & 0,69 & 0,54 \\
\hline Wsk. wypłaty dywidend & 0,09 & 0,13 & 0,08 \\
\hline Pieniężny wskaźnik pokrycia dywidend & 11,65 & 7,88 & 12,93 \\
\hline
\end{tabular}

Źródło: opracowanie własne na podstawie sprawozdań finansowych spółki X za lata 2013-2015. 
Wskaźnik ogólnej wystarczalności pieniężnej w roku 2013 świadczy o zdolności pokrycia najważniejszych źródeł wydatków w 88\%. W kolejnych latach wskaźnik ten spadł do 49\%, a następnie do $41 \%$ w 2015 r., co zwiększa ryzyko płynności i sygnalizuje konieczność zwiększenia kapitału własnego lub wzrostu finansowania obcego.

Ogół zadłużenia przewyższa zabezpieczenie w postaci generowanych wolnych środków pieniężnych 3,57 razy w 2013 r., następie w 2014 r. w momencie spadku zysków z działalności wskaźnik zwiększa się do 6,33. W 2015 r. ogół zadłużenia spada i przewyższa nadwyżkę środków pieniężnych 4,73 razy.

Odsetki od zobowiązań są pokryte przez dodatnie przepływy w analizowanym okresie na poziomie od 10,84 do 7,87 w 2015 r. Obniżenie wskaźnika w 2014 r. było efektem zwiększonych kosztów finansowych, przy jednoczesnym spadku przepływów operacyjnych.

W latach 2013-2015 udział amortyzacji w operacyjnych przepływach pieniężnych netto ulegał wahaniom, od poziomu 42\% do 54\% w 2015 r. Wzrost wskaźnika do 69\% w 2014 r. był spowodowany wzrostem amortyzacji przy jednoczesnym spadku dodatnich operacyjnych przepływów pieniężnych.

Pieniężny wskaźnik pokrycia dywidend pokazuje wahania relacji operacyjnych przepływów netto do dywidend w tym okresie, jednak przez cały analizowany okres wypłata dywidend była zabezpieczona nadwyżkę operacyjną na poziomie $11,65-12,93$.

\section{RÓŻNICE W OCENIE SYTUACJI FINANSOWEJ SPÓŁKI W ZALEŻNOŚCI OD WYBRANEJ GRUPY WSKAŹNIKÓW PŁYNNOŚCI FINANSOWEJ}

Z punktu widzenia właścicieli i udziałowców, największe znaczenie w działalności przedsiębiorstwa, ma jego zdolność do maksymalizacji zysku i wartości rynkowej. Przy założeniu działalności operacyjnej jako głównego czynnika determinującego efektywność spółek i wpływającego na maksymalizację ich wartości, niezwykle istotna jest analiza efektywności działalności operacyjnej i płynności finansowej. Na stopień maksymalizacji wartości dla właścicieli mają wpływ generowane nadwyżki środków pieniężnych przez spółkę. Tylko racjonalna polityka zarządzania, zarówno strukturą kapitałową, jak i stricte kapitałem obrotowym, jest w stanie zagwarantować osiągnięcie dodatnich wyników finansowych, które pozwolą zarówno na wzrost wartości dla właścicieli, jak też dalszy rozwój przedsiębiorstw na rynku oraz na tle konkurencji.

Analizując sytuację finansową poprzez jedynie statyczne wskaźniki płynności, możemy stwierdzić wyłącznie, iż wahania posiadanej płynności zależą od zmian wielkości aktywów obrotowych bądź zobowiązań bieżących w danym 
okresie. Nie uzyskujemy jednak informacji, co jest przyczyną powstałych zmian oraz kierunków wydatkowania niewykorzystanych nadwyżek pieniężnych z wcześniejszych lat. Wskaźniki te nie umożliwiają również określenia, w których segmentach działalności następuje zapotrzebowanie na zwiększone finansowanie. Na podstawie wartości z tab. 2 możemy stwierdzić, że spółka $X$ poprawiła swoją płynność w roku 2014 dzięki obniżeniu wartości zobowiązań, przy jednoczesnym wzroście aktywów bieżących oraz dodatnim wyniku finansowym. Na pogorszenie sytuacji w 2015 r. ma wpływ strata na działalności, a także zwiększone zapotrzebowanie na kapitał krótkoterminowy. Nie jest tu widoczna żadna tendencja w zakresie utrzymywania poziomu zadłużenia. Spółka realizuje agresywną strategię zarządzania strukturą kapitału, przy jednoczesnym wykorzystywaniu korzyści płynących z wykorzystywania finansowania obcego, kosztem podwyższonego ryzyka finansowego (spadek udziału kapitału własnego na korzyść finansowania obcego). W strukturze majątku przeważają aktywa trwałe, natomiast majątek obrotowy jest finansowany kapitałem obcym.

Analiza finansowa spółki za pomocą dynamicznych wskaźników płynności dostarcza bardziej precyzyjnych danych. Głównym źródłem generowanych przepływów gotówkowych jest podstawowa działalność operacyjna. Spółka X odnotowała dodatnią nadwyżkę finansową jedynie w 2014 r., jednak dzięki nadwyżkom z poprzednich lat, corocznie kończyła rok obrotowy z dodatnią wartością środków pieniężnych będących do dyspozycji przedsiębiorstwa. Zwiększone wydatki na działalności inwestycyjnej były finansowane z podstawowej działalności, a brakujące środki zostały pokryte przez kapitał obcy.

Zarówno wydajność gotówkowa sprzedaży, majątku, jak i wydajność zysku uległa w ostatnim roku pogorszeniu. Możemy określić, iż w strukturze majątku, największą wydajnością cechuje się majątek obrotowy. Wskaźniki te sygnalizują także nieznaczną, ale wzrostową, tendencję rosnącą wydajności kapitału własnego. Są to niezwykle istotne informacje dla kadry zarządzającej.

Wskaźniki dynamiczne eksponują także wystarczalność gotówkową spółki, w stosunku do posiadanego zadłużenia, zobowiązań odsetkowych, amortyzacji czy też w odniesieniu do wypłacanych dywidend. Wobec tego możemy stwierdzić m.in. że spółka X, w badanym okresie, wypracowywała operacyjną nadwyżkę pieniężną w kwocie wystarczającej do pokrycia wydatków z podstawowej działalności spółki. Ponadto sygnalizują fakt utrzymywania przez spółkę niskiego poziomu gotówki w stosunku do wartości zobowiązań.

Zdefiniowanie dodatkowego podziału wskaźników dotyczących poszczególnych sfer działalności, pozwala na precyzyjną analizę sytuacji finansowej z konkretnej działalności przedsiębiorstwa. Dzięki temu widzimy, że spółka $\mathrm{X}$ ma zwiększone wydatki finansowe na działalności inwestycyjnej, natomiast w działalności finansowej przeważają wydatki nad wpływami, a jedynie w 2014 r. spółka ta wygenerowała nadwyżkę z działalności. 
Dzięki wskaźnikom wystarczalności pieniężnej, zarządzający mają możliwość oceny i planowania zapotrzebowania na środki pieniężne, w zależności od intensywności wydatków w dany okresie. Są to dane szczegółowe, niemożliwe do określenia poprzez statyczne wskaźniki płynności finansowej.

\section{PODSUMOWANIE}

Analiza płynności, która stanowi wczesny sygnał potencjalnego zagrożenia niewypłacalności, jest niezwykle istotną dziedziną, która umożliwia zachowanie właściwego poziomu płynności, która gwarantuje postrzeganie firmy jako podmiotu stabilnego, o perspektywach rozwojowych, które są podstawą maksymalizacji zysków dla właścicieli przedsiębiorstwa. Pomimo braku obligatoryjności stosowania wskaźników dynamicznych w analizie sytuacji finansowej, warto rozważyć ich zastosowanie w celu uzupełnienia posiadanych danych finansowych. Zapewniają one bowiem uzyskanie precyzyjnych informacji dotyczących konkretnych obszarów realizowanej działalności. Umożliwiają większą elastyczność w podejmowaniu decyzji i dostosowywaniu się do nieprzewidzianych działań. Przekłada się to na wzrost konkurencyjności, który zwiększa zainteresowanie kapitałodawców i inwestorów, co jest niezwykle istotne w aktualnej, dynamicznej gospodarce rynkowej.

\section{BIBLIOGRAFIA}

Gołębiowski G., Grycuk A., Tłaczała A., Wiśniewski P., 2014, Analiza finansowa przedsiębiorstwa, Wydawnictwo Difin SA, Warszawa.

Grabowska M., 2012, Zarządzanie płynnościa finansowa przedsiębiorstw, CeDeWu, Warszawa.

Janik W., Paździor A., 2011, Zarządzanie finansowe w przedsiębiorstwie, Wydawnictwo Politechniki Lubelskiej, Lublin.

Kowalska S., 2013, Znaczenie płynności finansowej $w$ zarządzaniu przedsiębiorstwem $w$ sytuacjach kryzysowych, ,Zeszyty Naukowe Uniwersytetu Szczecińskiego nr 757: Finanse, Rynki Finansowe, Ubezpieczenia", nr 58.

Kreczmańska-Gigol, K., 2015, Płynność finansowa przedsiębiorstwa: istota, pomiar, zarządzanie, Wyd. Difin SA, Warszawa.

Kusak A., 2004, Ptynność finansowa. Analiza i sterowanie, Wydawnictwo Naukowe Wydziału Zarządzania Uniwersytetu Warszawskiego, Warszawa.

Nesterak J., 2014, Controlling zarządczy, Projektowanie $i$ wrażanie, Oficyna Wolters Kluwer Business, Warszawa.

Niemiec A., 2014, Wielkości graniczne statycznych wskaźników płynności finansowej, „Zeszyty Teoretyczne Rachunkowości”, t. 79(135), SKwP, Warszawa.

Śnieżek E., Wiatr M., 2015, Przeptywy pieniężne, wydanie II poszerzone, Wolters Kluwer, Warszawa. 
Tokarski A., Tokarski M., Mosionek-Schweda M., 2014, Pomiar i ocena plynności finansowej podmiotu gospodarczego, CeDeWu, Warszawa.

Wajszczuk K., 2013, Rachunek przepływów pieniężnych $w$ teorii $i$ praktyce. Program komputerowy: Cash Flow system, Difin, Warszawa.

\title{
THE ROLE OF THE DYNAMIC FINANCIAL LIQUIDITY RATIOS IN CORPORATE
} MANAGEMENT

\begin{abstract}
:
Purpose - The purpose of this article is to identify the role and importance of the data on the financial liquidity achieved through standard, static liquidity ratios, and the alternative, dynamic liquidity ratios, from the point of view of the company management.

Research Methodology - In the article was made an analysis of financial data of company X quoted on the Warsaw Stock Exchange from the point of view of liquidity management. This analysis was carried out in two variants: static and dynamic.

Result - The study evaluated the usefulness of the information of data indicators from the point of view of management and strategic cash management in the context of maximizing profits for the owners.

Originality/value - The study rated the indicator values are the real reflect the current situation of the company. This information allows management to rational financial management which enables the timely repayment, financing of investments and long-term development of the market.
\end{abstract}

Keywords: financial liquidity, business management, dynamic indicators. 